\title{
Teachers' Teaching Experience and Students' Learning Outcomes in Secondary Schools in Ondo State, Nigeria
}

\author{
Adeyemi, T. 0. \\ Department of Educational Foundations \& Management, \\ University of Ado- Ekiti, P. M. B 5363, Ado- Ekiti, Nigeria. \\ E-mail:toade1957@yahoo.com
}

\begin{abstract}
This article examined teachers' teaching experience and students' learning outcomes in the secondary schools in Ondo State Nigeria. As a correlational survey, the study population comprised all the 257 secondary schools that presented students for the year 2003 senior secondary certificate (SSC) examinations in the State. Out of the population, a sample of 180 schools was drawn through the process of stratified random sampling technique. An inventory and a semi-structured interview schedule were the instruments used to collect information for the study. The data collected were analysed using the chi square test, correlation analysis and t-test. The semi-structured interview was conducted with selected principals and education officers. Their responses were analysed through content analysis. The findings revealed that teachers' teaching experience was significant with student' learning outcomes as measured by their performance in the SSC examinations. Schools having more teachers with five years and above teaching experience achieved better results than schools having more teachers with less than five years teaching experience. Considering the findings, it was recommended that government should encourage experienced teachers to stay on the job through the provision of incentives such as better promotional prospects, better welfare package and better conditions of service.
\end{abstract}

Keywords: $\quad$ teaching experience, students' learning outcomes, teacher incentives

\section{Introduction}

The importance of experienced teachers in schools has been highlighted by many researchers (Akinleye, 2001; Ogundare 2002; Commeyras, 2003). Researchers have also given different opinions about teaching experience and students' learning outcomes in schools (Al-methen, 1983; Schuler, 1984; Waiching, 1994; Ijaiya, 2000; Akomolafe, 2001). Their arguments were centred on the fact that experience improves teaching skills while pupils learn better at the hands of teachers who have taught them continuously over a period of years (Ijaiya, 2000). In investigating possible differences in teaching strategies, Schuler (1984) grouped teachers into three levels of teaching experience (3-6; 7-10 and more than 10 years). His findings revealed that experienced teachers' perception of their teaching objectives were significantly more subject-oriented than were those of first-year teachers. Hence, effective teaching could be measured by the level of a teacher's subject matter competence which Mullens (1993) regarded as a prime predictor of student's learning. However, teachers' theories about teaching are being guided by their previous experience as learners and as teachers (Waiching 1994).

The importance of experienced teachers in schools has been argued as being necessary for school's effectiveness. Notwithstanding, Tahir (2003) reported poor teaching process exhibited by inexperienced teachers as among the many problems of educational development in Nigeria. This suggests that many experienced teachers might have left the school system probably as a result of better job prospects in other sectors of the economy. However, the desire by government to engage more teachers of long years standing is perhaps hampered by the cost of funding. Hence, Adeyemi (1998) exclaimed that the more experienced teachers in a school system, the higher would be the recurrent cost of education. As such, Charles (2002) suggested the need to involve retired teachers because of their long years of teaching experience to teach in Nigerian schools.

In terms of students' learning outcomes, Blaug (1970) argued that there are positive associations between personal earnings and schooling. He reported that the extension of education tends to raise the earnings of 
those who benefited from it (Blaug 1983). Schultz (1963) classified the outcomes of education into two categories from the economic point of view. These are consumption and investment. Cohn (1975) referred to the consumption aspect as that related to the benefits derived by students, their families and the society as a whole. He regarded the investment component as including a variety of outputs related to the enhancement of an individual's or society's productive skills and future well being. In this regard, Simkins (1981) reported that output represents the immediate results of the system's activities. According to him, the main outputs in education are expressed in terms of learning, that is, changes in the knowledge, skills and attitudes of individuals as a result of their experiences.

Tsang (1988) supported this view and regarded inputs to education as the various ingredients used in producing outputs. He remarked that the output of education consists of educational effects such as cognitive and non-cognitive skills that are learned by students. Hence the remark made by Sheehan (1973) that education yields benefits, which are 'consumed' over a long period (i.e. the life-time of the educated person). As such, education is an end in itself irrespective of any future benefits. Lord (1984) supported these views and enumerated four major areas of measuring output in education. These include the assessment by the teacher; standard examinations as a measure of educational output; other standardised tests for national and local monitoring and market research techniques.

Blaug and Woodhall (1968) made an attempt to measure the output of education. According to them, the simplest measure of secondary school output is the annual number of school leavers while the only measure of performance which could be applied to school leavers is the attainment in GCE examinations. Consequently, they measured output in terms of the number of school leavers weighted by different indices of quality or number of passes. They reported that "achievement in GCE is therefore, one relevant criterion of educational quality and that 'academic index' measures output in terms of GCE results. In the light of this, Thias and Carnoy (1972) examined the influence of school factors on the quality of schools' output in Kenya. According to them "the quality of output is equated with students' examination performance." They argued that if the average examination performance in one school is higher than in another, the quality of output of the first is considered to be higher than that of the second. Akangbou (1985) too, calculated the 'academic index' of output in Nigeria and remarked that the simplest measure of output of the Nigerian secondary education system is the number of school leavers.

As a measure of students' learning outcomes, examination occupies a central place in the Nigerian educational system and it has been the sole criterion of quality (Ukeje, 1966). Although the SSC examinations has replaced the WASC and GCE examinations in Nigeria, it still uses the GCE ' $O$ ' \& ' $A$ ' level standards as its norms since it was pitched between the 'O' \& 'A' level standards (Salami 1992). The pattern of grading candidates' scores in the examinations was such that the distinction grade was represented by A1 to B3. The credit grade was represented by $\mathrm{C} 4$ to $\mathrm{C} 6$. The ordinary pass grade was represented by D7 and E8 while the failure grade was represented by F9. It needs to be mentioned however, that the distinction and credit grades are the only requisite qualifications for admissions into universities in Nigeria and candidates must have at least five credits in five subjects including English Language in order to qualify for admission (JAMB 2002).

Several studies have found a positive effect of experience on teachers' effectiveness; specifically, the learning by doing" effect is most obvious in the early years of teaching (Dunkin, 1997, Rice, 2004, Bauer m 2005). In measuring teachers' effectiveness, Stiggins and Duke (1990) suggested three, parallel evaluation systems. These include an induction system for novice teachers with a focus on meeting performance standards; a remediation system for experienced teachers in need of remediation to correct deficiencies in performance and a professional development system for competent, experienced teachers pursuing excellence in particular areas of teaching. Notwithstanding, Glass (1990) found in a study that the pupil-achievement data could not tell teachers how to teach or distinguish between good and poor teachers. Medley and Shannon (1994) too, expressed doubts about using measures of student achievement to judge teacher effectiveness while Darling-Hammond, Wise and Klein (1995) found certain deficiencies in the attempts to obtain performance measures of teachers: These deficiencies include the fact that the assessment systems do not evaluate candidates in similar job settings and performance situations. Considering the foregoing, the objective of this study was to examine teachers' teaching experience in secondary schools in Ondo state, Nigeria and determine whether teaching experience had any relationship with students' learning outcomes. 
Teachers' Teaching Experience and Students' Learning Outcomes in Secondary Schools in Ondo State, Nigeria Adeyemi, T. O.

\section{Statement of the Problem}

A common observation of the school system in Ondo State, Nigeria would show a large number of young teachers with few years of teaching experience. Many of these teachers seem to lack the much needed experience that could bring about effective teaching and learning in schools in terms of teaching methodology (Ondo State Ministry of Education, 2002). Hence teaching tends to done in abstract while learning is perhaps by rote memory. The problem of this study was to determine relationship exist between teachers' teaching experience and students' learning outcomes in secondary schools in Ondo State, Nigeria? In addressing this problem, the following research questions were raised:

1. How are teachers distributed on the basis of teaching experience to urban and rural secondary schools in Ondo State, Nigeria?

2. What is the level of students' learning outcomes in schools?

3. Is there any relationship between teachers' teaching experience and students' learning outcomes as measured by their performance in SSC examinations in the State?

4. Is there any difference between the SSC examinations performance of students in 'schools having more teachers with above twelve years teaching experience' and those in 'schools having more teachers with twelve years or less teaching experience' in the Ondo State, Nigeria?

\section{Method}

This study was designed to follow the strategies of a correlational survey. Gay (1996) described a correlational study as one that involves the collecting of data in order to determine whether, and to what degree, a relationship exists between two or more quantifiable variables. Anderson (1998) regarded correlational research as involving the calculation of a correlation coefficient which is a measure of the extent to which variables vary in the same way. In this regard, the study population comprised all the 257 secondary schools that presented candidates for the year 2003 Senior Secondary Certificate examinations in Ondo State of Nigeria. Out of this, a sample of 180 schools ( $70 \%$ of the study population) was drawn through the process of stratified random sampling technique. The instrument used to collect data was an inventory titled 'secondary schools teachers' teaching experience and students' learning outcomes inventory' and a semi-structured interview schedule titled 'teachers' teaching experience and students' learning outcomes interview schedule'. The inventory consisted eight items. Items 1-6 elicited information on the name of the school, its location (whether urban or rural), school type, students' enrolment, number of classes and number of years of teaching experience of teachers. Item 7 requested for data on students' grades in four core subjects (Nigerian National Policy on Education, 1998) in the junior secondary certificate (JSC) examinations for three years 1997, 1998 and 1999. Item 8 requested for data on students' grades in five other core subjects namely English Language, Mathematics, Physics, Chemistry and Biology in the year 2000, 20012002 and 2003 SSC examinations. The data collected were analysed with the use of percentages, chi-square test, correlation coefficient and t-test. The semistructured interview was conducted with 36 principals and 36 education officers randomly selected from a population of 257 principals and 351 education officers in the State's Ministry of Education. The proportion of the number of responses was computed through the content analysis technique based on a maximum obtainable score of 100\% (Easterby-Smith, Thorpe, \& Lowe 1996). 


\section{Data Analysis}

\section{Distribution of teachers on the basis of teaching experience to urban and rural secondary schools in Ondo State, Nigeria}

In responding to this question, data on the number of schools having teachers with varying numbers of years of teaching experience were collected and analysed with the use of percentages. The findings are indicated in table 1.

Table 1 Number of teachers with years of teaching experience by location

\begin{tabular}{|c|c|c|c|c|c|c|c|}
\hline \multirow[t]{3}{*}{ Location } & \multicolumn{4}{|c|}{$\begin{array}{l}\text { Schools having more teachers with } \\
\text { varying number of teaching experience }\end{array}$} & \multirow[t]{2}{*}{ Total } & \multirow[t]{2}{*}{$\begin{array}{c}\text { Chi } \\
\text { square } \\
\text { (Pearson) } \\
\end{array}$} & \multirow[t]{2}{*}{ Signif. } \\
\hline & Above & $9-12$ & $5-8$ & Below 5 & & & \\
\hline & 12 years & years & years & years & & 13.2 & .00 \\
\hline Rural & 10 & 12 & 21 & 19 & 62 & & \\
\hline Urban & 13 & 23 & 47 & 35 & 118 & & \\
\hline Total & 23 & 35 & 68 & 54 & 180 & & \\
\hline
\end{tabular}

As shown in table 1,13 urban schools $(56.5 \%)$ out of the 23 schools had more teachers with above 10 years teaching experience while rural only 10 schools (43.5\%) had above years teaching experience. On the other hand, 35 urban schools $(64.8 \%)$ out of the 54 schools had more teachers with below five years teaching experience while only 19 rural schools (35.2\%) had more teachers with below five years teaching experience. As such, urban schools had relatively more teachers with longer years teaching experience than rural schools. The chi square analysis shows significant relationship between school-location and teaching experience.

\section{Level of students' learning outcomes in secondary schools in Ondo State, Nigeria}

Students' learning outcomes was examined in this study in terms of the performance level of students in the junior secondary certificate (JSC) and the senior secondary certificate (SSC) examinations. In determining the level of students' learning outcomes in the schools, performance in the two terminal level examinations (JSC and SSC examinations) was computed. Thus, the frequency counts of the number of students who obtained credit grades 1 to 6 (credit grades) in each subjects in the examinations were transformed from discrete data into continuous data through secondary analysis. The weighted average performance is computed using the formula:

$$
\begin{array}{ll}
P=\frac{n_{1} A_{1}+n_{2} A_{2}+n_{3} A_{3}+n_{4} A_{4}+n_{5} A_{5}+n_{6} A_{6}}{N} \\
\text { where: } \begin{array}{l}
\mathrm{P} \rightarrow \text { performance } \\
\mathrm{n}_{1}, \mathrm{n}_{2} \ldots \mathrm{n}_{6} \rightarrow \text { number of times each grade occurs. } \\
\mathrm{A}_{1}, \mathrm{~A}_{2}, \ldots \mathrm{C}_{6} \rightarrow \text { numeric weights of each grade. }
\end{array}
\end{array}
$$

The level of students' learning outcomes was determined in two stages. The first stage was the determination of the level of performance of students in the core subjects in the junior secondary certificate (JSC) examinations while the second stage was the determination of the level of performance of students in the core subjects in the senior secondary certificate (SSC) examinations. The grades obtained by students in the JSC and SSC examinations in the various subjects were collected form the State's Ministry of Education. Table 2 shows the performance level of the students in the core subjects in the junior secondary certificate (JSC) examinations. 
Teachers' Teaching Experience and Students' Learning Outcomes in Secondary Schools in Ondo State, Nigeria Adeyemi, T. O.

Table 2.1 Performance level of students in the JSC examinations in Ondo State, Nigeria

\begin{tabular}{lllll}
\hline Years & $\begin{array}{l}\text { English language } \\
\%\end{array}$ & $\begin{array}{l}\text { Mathematics } \\
\%\end{array}$ & $\begin{array}{l}\text { Integrated Science } \\
\%\end{array}$ & $\begin{array}{l}\text { Social Studies } \\
\%\end{array}$ \\
\hline 1997 & 45.7 & 37.2 & 43.5 & 46.4 \\
1998 & 46.3 & 39.6 & 47.7 & 49.1 \\
1999 & 49.1 & 58.5 & 51.2 & 52.9 \\
\hline
\end{tabular}

Source: Statistics Division, Ministry of Education, Akure

As indicated in Table 2.1, the performance level of students in each of the four subjects in the junior secondary certificate examinations was low. In the senior secondary certificate (SSC) examinations, lowlevel results were also obtained in the State. Table 2.2 shows the findings.

Table 2.2 Performance in the SSC Examinations in Ondo State, Nigeria

\begin{tabular}{llllll}
\hline Years & English language & Mathematics & Physics & Chemistry & Biology \\
\hline & $\%$ & $\%$ & $\%$ & $\%$ & $\%$ \\
2000 & 4 & 10 & 8 & 23 & 10 \\
2001 & 5 & 12 & 11 & 25 & 16 \\
2002 & 8 & 15 & 18 & 27 & 24 \\
\hline
\end{tabular}

Source: Statistics Division, Ministry of Education, Akure

As shown in Table 2.2, the performance level of students was also low in each of the subjects in the SSC examinations for the three years. This tends to confirm the low level of students' learning outcomes in the schools.

\section{Relationship between teachers' teaching experience and students' learning outcomes as measured by their performance in SSC examinations}

In analysing this question, correlation analysis was utilised and a correlation matrix was derived. The findings are indicated in Table 3.

Table 3: Correlation Matrix in Respect of Each Pair of Variables

\begin{tabular}{|c|c|c|c|c|c|c|c|}
\hline Variables & $\begin{array}{l}\text { Credit Scores } \\
\text { SSC } 2003\end{array}$ & $\begin{array}{c}\text { School } \\
\text { Location }\end{array}$ & $\begin{array}{c}\text { Exp. } \\
\text { English }\end{array}$ & $\begin{array}{l}\text { Exp. } \\
\text { Math. }\end{array}$ & $\begin{array}{c}\text { Exp. } \\
\text { Physics }\end{array}$ & $\begin{array}{c}\text { Exp. } \\
\text { Chemistry }\end{array}$ & $\begin{array}{c}\text { Exp. } \\
\text { Biology }\end{array}$ \\
\hline $\begin{array}{l}\text { Credit Scores } \\
\text { SSC } 2003 .\end{array}$ & 1.00 & & & & & & \\
\hline $\begin{array}{l}\text { School } \\
\text { Location }\end{array}$ & $.41^{*}$ & 1.00 & & & & & \\
\hline Exp. English. & $.28 *$ & $.39 *$ & 1.00 & & & & \\
\hline Exp. Math. & $.25^{*}$ & $.34 *$ & $.32 *$ & 1.00 & & & \\
\hline Exp. Physics. & $.27 *$ & $.29 *$ & $.24^{*}$ & $.42 *$ & 1.00 & & \\
\hline $\begin{array}{l}\text { Exp. } \\
\text { Chemistry. }\end{array}$ & $.34^{*}$ & $.36^{*}$ & $.32 *$ & $.38 *$ & $.41 *$ & 1.00 & \\
\hline Exp. Biology. & $.38 *$ & $.35^{*}$ &. $.43 *$ & $.38 *$ & $.26^{*}$ & $.43^{*}$ & 1.00 \\
\hline
\end{tabular}


In Table 3, the correlation matrix shows the correlation coefficients between each pair of variables and their respective probability 'p', which was less than 0.05 level of significance for each pair of variables. This shows that there was a significant relationship between each pair of variables. It further shows a significant relationship between teachers' teaching experience and students' learning outcomes as measured by their performance in SSC examinations in the Stats.

\section{Difference between the SSC examinations performance of students in 'schools having more teachers with above twelve years teaching experience' and those in 'schools having more teachers with twelve years or less teaching experience' in Ondo State, Nigeria}

In response to this problem, the research question was transformed to the following null hypothesis:

Ho There was no significant difference in the achievement of students in SSC examinations schools having more teachers with above twelve years teaching experience and schools having more teachers with twelve years and less than twelve years teaching experience in Ondo State, Nigeria.

In testing the null hypothesis, data on the SSC results in English Language, Mathematics, Physics, Chemistry and Biology for year 2001 were used. The schools were classified into two groups. The first group consisted of schools having more teachers with above twelve years teaching experience while the second group contained schools having more teachers with twelve years and less than twelve years teaching experience. The $t$ - test findings are shown in table 4.

Table $4 \quad$ t- test analysis of scores

\begin{tabular}{|c|c|c|c|c|c|c|c|c|}
\hline Subjects & $\begin{array}{l}\text { Schools having } \\
\text { teachers with years of } \\
\text { Teaching Experience. }\end{array}$ & $\mathbf{N}$ & Mean & SD & 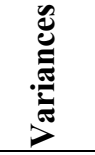 & df & $\begin{array}{c}\text { t- } \\
\text { value }\end{array}$ & $\begin{array}{l}2 \text { Tail } \\
\text { Signif. }\end{array}$ \\
\hline \multirow[t]{2}{*}{ English } & $>12$ Years & 118 & .21 & .22 & Equal & 178 & $4,52 *$ & .00 \\
\hline & $<12$ Years & 62 & .11 & .12 & & & & \\
\hline \multirow[t]{2}{*}{ Mathematics } & $>12$ Years & 118 & .20 & .21 & Equal & 178 & $5.61^{*}$ & .00 \\
\hline & $<12$ Years & 62 & .09 & .08 & & & & \\
\hline \multirow[t]{2}{*}{ Physics } & $>12$ Years & 118 & .21 & .22 & Equal & 178 & $6.72 *$ & .00 \\
\hline & $<12$ Years & 62 & .11 & .10 & & & & \\
\hline \multirow[t]{2}{*}{ Chemistry } & $>12$ Years & 118 & .24 & .23 & Equal & 178 & $6.43^{*}$ & .00 \\
\hline & $<12$ Years & 62 & .13 & .12 & & & & \\
\hline \multirow[t]{2}{*}{ Biology } & $>12$ Years & 118 & .28 & .27 & Equal & 178 & $7.45^{*}$ & .00 \\
\hline & $<12$ Years & 62 & .14 & .15 & & & & \\
\hline
\end{tabular}

As indicated in Table 4, the t- test shows equal variances while the calculated t- value was greater than the table t-value in each of the subjects. Hence, the probability ' $p$ ' was less than 0.05 in all the subjects. This indicates a significant difference in the achievement of students between schools having more teachers with above twelve years teaching experience and schools having more teachers with twelve years and less than twelve years teaching experience in the subjects. Schools having more teachers with above twelve year teaching experience achieved better results than schools having teachers with twelve years and less than twelve years teaching experience. The mean scores were higher in schools having more teachers with above twelve years teaching experience than in schools having more teachers with twelve years and less than twelve years of teaching experience.

\section{Analysis of the Interviews}

The use of the interview to supplement questionnaires has been emphasised by many researchers (Warwick and Lininger, 1975, Weisberg and Bowen, 1977). Warwick and Lininger (1975) for instance, remarked that a survey interview is a form of verbal interaction designed to obtain information about a study. Weisberg and Bowen (1977) too, reported that the interview is an instrument designed to assist in getting candid answers from respondents. They argued that personal interviews can be used to obtain large amounts of information. In selecting the 36 principals, therefore, consideration was given to the urban and rural location of schools as well as the principals to be interviewed. Hence, 2 principals were selected 
Teachers' Teaching Experience and Students' Learning Outcomes in Secondary Schools in Ondo State, Nigeria Adeyemi, T. O.

from each of the 18 local government areas in the State thereby making a total of 36 principals in the sample. Two education officers were also selected from each of the 18 local government areas thereby making a total of 36 education officers. Considering the suggestions made by Oppenheim (1992, p.70) that the interview should be natural, maintaining the fiction of an interesting conversation, the researcher itemised the topics on which questions would be raised. At the end of the interviews, the responses were analysed using the content analysis technique which involved counting the number of responses per question and finding the proportion of the number of respondents who made the responses. The findings made are as follows:

Question 1 Do you think that there were enough teachers having long years of teaching experience in secondary schools in the State?

Responding to this question, 19 of the principals (95\%) and 16 of the education officers were of the opinion that there was inadequacy in the number of experienced teachers in secondary schools in the State, They claimed that a visit to most schools would reveal that most of the experienced teachers in the various subjects had either retired or left the teaching profession for other lucrative jobs thereby making the turnover rate among secondary school teachers to be somehow high in the State.

Question 2 Do you think that experienced teachers in the various subjects could bring about better performance among students in secondary schools in the State?

In response to this question, all the principals (100\%) and 18 of the education officers (90\%) reported that considering the common saying that experience is the best teacher, teachers of long years of teaching experience always have better ways of teaching, better strategies or methods to apply at any given situation and better ways of bringing the subject matter being taught to students. According to them, this would inevitably lead to better students' learning outcomes in schools.

Question 3 Do you think that there is any relationship between the availability of teachers with long years of teaching experience s in schools and students learning outcomes?

Answering this question, all the principals $(100 \%)$ and education officers $(100 \%)$ reported that the presence of teachers with long years of teaching experience in schools has much relationship with students' learning outcomes.. They claimed that ss major inputs into the school's system and the hub of the educational system, teachers are a force to reckon with in schools in terms of effective teaching and better learning outcomes.

Question 4 Do you think that there are more teachers with long years of teaching experience in urban schools at the expense of rural schools?

In response to this question, 17 of the principals (85\%) and 19 of the education officers were of the view that experienced teachers are more in urban secondary schools than in rural schools in the State. As many as 19 of the principals (95\%) and 18 of the education officers $(90 \%)$ also claimed that experienced teachers leave rural schools at a high rate because many of them perhaps do not want to work on rural areas thereby making the turnover rate of teachers to be higher in rural schools than in urban schools.

\section{Question 5 Give suggestions that could bring about an improvement?}

Responding to this question, all the principals (100\%) 18 of the education officers (90\%) suggested that teachers should be given better motivation in terms of better incentives to make them stay on the job. They also suggested that schools could engage the services of some retired teachers in certain subjects such as English Language, Mathematics, Physics Chemistry and biology which are core subjects in secondary school curriculum. This would assist schools in their deriving better teaching strategies that could lead to better learning outcomes in students and better performance in the senior secondary certificate examinations.

\section{Discussion}

In the foregoing, the analysis of data in respect of the relationship between teacher experience and students learning outcome was made. The findings showed a significant relationship between teachers' teaching 
experience and students' academic achievement in the SSC examinations in Ekiti State, Nigeria. The findings indicating significant differences in the students' achievement in all the subjects were consistent with Almethen's (1983) findings in Kuwait who reported that teachers' teaching behaviours were strongly related to pupils' achievement. The findings were in agreement with Razouki's (1987) findings in Iraq which emphasized that teaching experience correlated significantly and positively with academic achievement. They were also in consonance with Kwari's (1989) findings in Sokoto State, Nigeria indicating that teaching experience was significantly related to students' achievement.

The findings were however, in contrast with the findings made by Zaku (1983) who found in the former Gongola State, Nigeria that teaching experience had a non-significant standardized partial regression of 0.06 and it made little contribution to the explained variance, The findings were also at variance with Dewalt's (1986) findings which showed no significant difference between teachers with teaching experience and teachers without teaching experience on teacher competencies in teaching methodology . The findings were in contrast with those of Schneider (1988) who found no statistical difference between novice and experienced teachers in relation to students' achievement.

The findings were however consistent with those of Heffley (1983) who discovered in Kansas, USA that the first-year teachers experienced significantly more classroom teaching problems than did teachers with more years of teaching experience while Sweeney (1989) reported that schools in Mississippi USA which scored in the lower $10 \%$ on the Mathematics portion of the American College Test (ACT) had teachers with more years of teaching experience. The findings supported those of Gomwalk (1986) who remarked that inexperienced teachers who fumble as they teach could only succeed in frustrating and scaring away science oriented students.

The findings were also consistent with those of Jones (1997) who claimed that students tend to achieve better results when taught by teachers with more years of teaching experience. The findings agreed with Adeyegbe's (2002) findings indicating that many students perform poorly in WAEC examinations in topics where teachers found difficult to teach as a result of in-experience in teaching methodology and content. Supporting this point, Oderinde (2003) remarked that teaching of students by unqualified teachers who are inexperienced in teaching methodology are among the reasons why many candidates find it difficult to pass their examinations. The responses made by the interviewees to the questions raised at the interview tend to buttress the findings of the study. They were of the view, however, that the inspection of schools by the State's Ministry of Education was not sufficient. Considering the common saying that experience is the best teacher, it is necessary to note that teachers who have been exposed to long years of teaching experience have the opportunity of attending the conference marking of scripts organised by the Examinations Councils thereby making them accustomed with the marking scheme in the various subjects and enhancing better teaching strategies. Teachers cannot be ignored in the overall conclusion if the views of the interviewees were regarded as complementary to the findings of this study. As key inputs into the school's system and the hub of the educational system, teachers are a force to reckon with in schools. But it seems that experienced teachers are not in large numbers in schools. Although the interviewees' responses were personal opinions, they cannot be totally ruled out as they tend to supplement the findings of this study.

\section{Conclusion}

The first conclusion in this study is that teaching experience was significant with students' learning outcomes in secondary schools in Ondo State of Nigeria. Schools having more teachers with above twelve years and above teaching experience achieved better results than schools having more teachers with twelve years and below twelve years teaching experience. This suggests that teaching experience is a critical variable in students' learning outcomes in schools. The findings also led the researcher to conclude that teachers with less than twelve years teaching experience are many in secondary schools in the State. This implies that perhaps, the turnover rate of experienced teachers might possibly have been very high in the schools. Based on the findings, it is recommended that the State Government should endeavour to encourage teachers to stay on the job through the provision of more incentives and fringe benefits for teachers. The State's Ministry of Education should intensify more efforts in the inspection and monitoring of schools to ensure that teachers stay on the job. Likewise, more studies need to be conducted on teacher turnover rate in schools. 
Teachers' Teaching Experience and Students' Learning Outcomes in Secondary Schools in Ondo State, Nigeria Adeyemi, T. O.

\section{References}

Adeyegbe, S. O. (2002) "How students perform at WAEC Examinations" Education and Manpower, Vanguard December 19, 22.

Adeyemi, J. K. (1998) "The cost of education" in Educational management for Sub-Saharan Africa, Mon Nwadiani (ed) Benin- City: Monose Amalgamates 75.

Akangbou, S. D (1985) The economics of educational planning in Nigeria New Delhi: Vikas Publishing House P.V.T Ltd, 76-117.

Akinleye, G. A. (2001) "Early childhood education: Guide for parents and teachers" UNAD Journal of Education, 2 (1) October; 45.

Al-Methen A.E. (1983) “Teacher Performance Characteristics and Pupils' Outcomes Within Science Classrooms in Kuwaiti High Schools." Unpublished Ph.D Thesis, University of Hull, United Kingdom, 129-145, 179- 200.

Anderson, G.\& Arsenaut, N. (1998) Fundamentals of educational research London: Falmer Press Taylor \& Francis Inc; 152.

Bauer, B S. (2005) Teaching english in Africa: Volunteer opportunities abound for young and old Retrieved (2005) from http:/www.peacecorps.gov/index.cfm

Blaug, M. \& Woodhall, M. (1968) "Productivity trends in British secondary education 1950 - 1963" Sociology of Education 41, (1) Winter, 2, 12-13.

Blaug, M. (1983) "Where are we now in the economics of education?" A Special Professorial Lecture delivered at the Institute of Education, University of London UK. Thursday, 16th June, 7-9.

Blaug, M. (1970) An introduction to the economics of education London: Allen Lane. The Penguine Press, 21-23; 61-120, 297-311.

Charles, H. (2002) "MPs should work on better funding" in Education Manpower by Wale Ajao in Vanguard Thursday, December, 19; 23.

Cohn, E. (1975) Input- output analysis in public education Cambridge, Massachussetts, USA: Ballinger Publishing Company, 1-7, 21-24.

Commeyras, M. (2003) "Promoting a culture of reading" The Comet Thursday, February 13, 32.

Darling-Hammond, L., Wise, A.E., \& Klein, S.P. (1995). A license to teach: Building a profession for 21st-Century schools. Boulder, CO: Westview Press 73-74..

Dewalt, M. W.(1986) "The effects of teacher training on teacher experience" Unpublished Ph.D Thesis, University of Virginia USA Dissertation Abstracts on CD Rom Order No. AAC 8716973.

Dunkin, M. J. (1997). Assessing teachers' effectiveness. Issues in educational research, 7(1), 37-51. http://education.curtin.edu.au/iier/iier7/dunkin.html

Easterby-Smith, M, Thorpe, R \& Lowe, Andy (1996) "Doing and completing the research Part three: Qualitative methods 5" Management research: An introduction London: Sage Publications in Module 4: Project Design and Consultancy Practice; Guide to Hull Teaching, P. Milne \& A. Ghazzali (Course Directors), 105-108.

Gay, L. R (1996) Educational research: Competencies for analysis and application Fifth Edition. Upper Saddle River, New Jersey: Prentice-Hall Inc, A Simon \& Schuster Company, 296-297.

Glass, G.V.. (1990). Using student test scores to evaluate teachers. In J. Millman \& L. Darling-Hammond (Eds.), The new handbook of teacher evaluation: Assessing elementary and secondary school teachers (pp.229-240). Newbury Park, CA: Sage. 61, 239. 
Gomwalk U.D. (1986) “The 1986 STAN conference” Daily Times Lagos; Daily Times of Nigeria Ltd. $10^{\text {th }}$ September. 18.

Heffley, R. C. (1983) "Factors affecting teacher turnover in Kansas" Unpublished Ph.D Thesis University of Kansas USA Dissertation Abstracts on CD Rom Order No AAC 8403594.

Ijaiya, N. Y. (2000) "Failing schools' and national development: Time for reappraisal of school effectiveness in Nigeria" Nigerian Journal of Educational Research and Evaluation (2): 2; 42.

JAMB (2002) UME/direct entry brochure: Guidelines for admissions to first degree courses in Nigerian universities 2003/2004 session Abuja: Joint Admissions and Matriculation Board, 47.

Jones, M. (1997) "Trained and untrained secondary school teachers in Barbados : Is there a difference in classroom performance?” Educational Research. Vol 39, No 2, Summer; 182.

Kwari Y. (1989) “The Relationship between selected educational variables and students' academic achievement in Sokoto State of Nigerian Secondary Schools" Unpublished PhD Thesis, Wayne State University USA. Dissertation Abstracts On CD Rom Order No AAC 8922763.

Lord, R. (1984) Value for money in education, London: Public Money, .8.

Medley, D. M. \& Shannon, D.M. (1994). Teacher evaluation. In T. Husen \& T.N. Postlethwaite (Eds.), The International encyclopedia of education, 2nd edn., Vol. 10, pp.6015-6020. Oxford: Pergamon.

Mullens, J. E (1993) “The relationship between teacher qualifications and students' learning: A study of standard one classrooms in Belize, Central America" Unpublished EDD Thesis, Harvard University USA. Dissertation Abstracts on CD Rom. Order No AAC 9326318.

Oderinde, B. B (2003) "Examinations and students' performance" Education \& Manpower, Vanguard, Thursday, January 16, 30.

Ogundare S. F (2001) "Purposes and problems of recess in Nigerian primary schools" UNAD Journal of Education 2 (1) October 2001; 4 - 8.

Ondo State Nigeria Ministry of Education (2002) "Educational statistics 2002" Akure: Statistics Section, 35.

Oppenheim, A N. (1992) Questionnaire design, interviewing and attitude measurement London \& New York: Pinter Publishers, 39-70.

Razouki A A.(1987) "Analysis of socio-economic factors on students' achievement in the preparatory academic schools in Iraq." Unpublished PhD Thesis University of Pittsburg USA_Dissertation Abstracts on CD Rom Order No AAC 8719318.

Rice, J. K.(2004) Teacher Quality understanding the effectiveness of teacherattributes The Economic Policy Institute EPI Books August, Retrieved (2004) from http://www.epinet.org/content.cfm.economist.

Salami, A (1992) "Raising the standard of performance in public examination" Paper Presented at the WAEC Symposium held at the University of Ibadan, Nigeria 24th April, 1-3.

Schneider K A (1988) "Teaching experience as a determinant of middle level teacher concerns" Unpublished PhD Thesis, Ball State University USA Dissertation Abstracts on CD Rom Order No AAC 8825970.

Schuler G W. (1984) "The effect of teaching experience on teachers' perceptions of their teacher preparation programs." Unpublished EDD Thesis, Temple University USA Dissertation Abstracts on CD Rom Order NO AAC 8410161.

Schultz, T.W (1963). The economic value of education, New York \& London: Columbia University Press, 20, 54-55.

Sheehan, J. (1973) The economics of education, London: George Allen and Unwin, 21-31. 
Teachers' Teaching Experience and Students' Learning Outcomes in Secondary Schools in Ondo State, Nigeria Adeyemi, T. O.

Simkins, T. (1981) Economics and the management of resources in education, Sheffield: Department of Educational Management, Sheffield City Polytechnic, UK, 5--7..

Stiggins, R.J., \& Duke, D.L. (1990). The case for commitment to teacher growth: Research on teacher evaluation. New York: State University of New York Press.

Sweeney J. D Sr. (1989) "A study of some factors that are related to mathematical achievement in Mississippi High Schools as Measured by Scores on the American College Test" Unpublished Ph.D Thesis The University of Mississippi USA Dissertation Abstracts on CD Rom Order No AAC 9005402.

Tahir, G. (2003) "Poor supervision of schools" in "what and where"? Vanguard; Thursday, January, 23; .25 .

Thias, H. H \& Carnoy, M. (1972) Cost benefit analysis in education: A case study of Kenya. Baltimore \& London: The International Bank for Reconstruction and Development \& The Johns Hopkins Press, $25,143$.

Tsang, M.C. (1988) "Cost analysis for educational policy making: A review of cost studies in education in developing countries" Review of Educational Research 58, (2) Summer, 181 - 230.

Ukeje, B.O. (1966) Education for social reconstruction London and Basingstoke: Macmillan Educational Books, 54-77, 88, 106.

Waiching, E. M. (1994) "Reflecting on reflections: A case study of experienced and inexperienced ESL teachers" System 22 (1) Pergamon Elsevier Science Ltd. 93.

Warwick, D. P \& Lininger, C. A (1975) The sample survey: theory and practice New York: McGrawHill Company; 46-71, 182 -220.

Weisberg, H. F \& Bowen, B. D (1977) An introduction to survey research and data analysis San Francisco: W H Freeman \& Company, pp. 13, 59-62, 97-106.

Zaku A.B.D. (1983) “The relationship between some school factors and students' performance in chemistry in the Gongola State of Nigeria" Unpublished PhD Thesis, University of Hull, United Kingdom. 86-88. 